\title{
Neutral metallacyclic rotors $\dagger$
}

\section{Malaichamy Sathiyendiran, ${ }^{a}$ Jing-Yun Wu, ${ }^{a}$ Murugesan Velayudham, ${ }^{a}$ Gene-Hsiang Lee, ${ }^{b}$ Shie-Ming Peng ${ }^{b}$ and Kuang-Lieh $\mathrm{Lu}^{* a}$}

Received (in Cambridge, UK) 23rd January 2009, Accepted 28th April 2009

First published as an Advance Article on the web 19th May 2009

DOI: $10.1039 / b 901535 c$

A prototype of a neutral Re-based metallacyclic rotor, assembled in a one-step process, possesses a para-phenylene rotor that rotates in solution with respect to the stator.

The intriguing design, synthesis and characterization of various types of molecular rotors has attracted great interest because rotating units are ubiquitous in natural systems, e.g. F1-ATPase, kinesin and the dynein family, DNA motors, motor proteins from myosin, and man-made machines. Examples of molecular-sized mechanical analogues are gears, brakes, turnstiles, compasses, gyroscopes, cogwheels, ratchets, shuttles, scissors, walkers and switches. ${ }^{2-6}$ Among these, discrete metallacyclic-based molecular rotors are rare., Recently, research has been directed to the design of elegant ionic metallacyclic molecular rotors, ${ }^{6,7}$ whereas the neutral metallacyclic rotor has remained elusive. This study reports on an efficient approach, i.e. the simple combination of fac- $\operatorname{Re}(\mathrm{CO})_{3}$-cores and bis(chelating) dianion with paraphenylene-incorporated semi-rigid ditopic ligands, to neutral metallacyclic rotors. This metallacycle contains a para-phenylene unit that rapidly rotates within the metallacycle.

Compound 1a was assembled by reacting equimolar amounts of $\operatorname{Re}_{2}(\mathrm{CO})_{10}$, 6,11-dihydroxy-5,12-naphthacenedione $\left(\mathrm{H}_{2}\right.$-dhnq) and $\alpha, \alpha^{\prime}$-bis(benzimidazole-1-yl)-para-xylene (benzbix) in a one-pot procedure (Scheme 1) $\ddagger$ The resulting dark green products are air-and moisture-stable and soluble in polar organic solvents. The IR spectrum of 1a exhibited strong bands at 2010, 1907 and $1883 \mathrm{~cm}^{-1}$, characteristic of fac- $\operatorname{Re}(\mathrm{CO})_{3}$ in an asymmetric environment. ${ }^{8}$ The FAB-MS analysis showed a molecular ion peak at $m / z 1168.4$, with the experimental isotope pattern matching calculated values and corresponding to a dirhenium metallacyclic structure. Following a similar procedure as for $\mathbf{1} \mathbf{a}$, metallacycles $\mathbf{1 b}$ and $\mathbf{2 a , b}$ were also synthesized.

A single-crystal X-ray diffraction analysis $\S$ at $150(1) \mathrm{K}$ showed that metallacycle 1a adopts a dinuclear chair-shaped structure (Fig. 1) and can be regarded as a molecular rotor, in which the dianionic dhnq unit is related to the stator, the para-xylene unit is related to the axle and the para-phenylene group is related to the rotor. The coordination sphere around

\footnotetext{
${ }^{a}$ Institute of Chemistry, Academia Sinica, Taipei 115, Taiwan. E-mail: lu@chem.sinica.edu.tw; Fax: +886 2-27831237;

Tel: +886 2-27898518

${ }^{b}$ Department of Chemistry, National Taiwan University, Taipei 107, Taiwan

$\dagger$ Electronic supplementary information (ESI) available: Synthesis and characterisation details of $\mathbf{2 a , b}$. Crystallographic and spectral data of 1a,b and 2a,b. CCDC 717894-717897. For ESI and crystallographic data in CIF or other electronic format see DOI: $10.1039 / \mathrm{b} 901535 \mathrm{c}$
}

the Re centers is a distorted $f a c-\mathrm{C}_{3} \mathrm{NO}_{2}$ octahedral geometry. The dianionic dhnq unit acts as a doubly-bridging unit using the chelating oxygen atoms. The benzbix ligand adopts a syn-conformation mode. The nearly face-to-face opposite benzimidazole units have separations ranging from 6.9 to $8.3 \AA$. The distance between the axle and the dhnq mean plane is $5.3 \AA$. The length of the dhnq stator is $11.38 \AA$. The dhnq unit and para-phenylene group of the benzbix unit are arranged in an almost edge-to-face arrangement, and the short distances between them $(\mathrm{C} 34 \cdots \mathrm{C} 103.73 \AA$ and $\mathrm{C} 35 \cdots \mathrm{C} 15$ $3.80 \AA$ ) indicate the existence of $\mathrm{C}-\mathrm{H} \cdots \pi$ interactions (Fig. $\mathrm{S} 1$, ESI $\dagger) .^{9 a}$ The lattice toluene molecules interact with both the dhnq and para-phenylene groups in the same molecule, similar to "benzene ring trimer" interactions (Fig. S1, ESI $\dagger$ ). ${ }^{9 b}$ When the diffraction analysis of 1a was performed at 295(2) K using different single crystals, no lattice solvent molecules were present and the benzbix ligand was site-disordered over two positions, with a site-of-occupancy of 0.5 (Fig. S3, ESI $\dagger$ ). The molecular structures of $\mathbf{1 b}$ and $\mathbf{2 b}$ (Fig. S4 and S5, ESI $\dagger$ ) are analogous to that of metallacycle $\mathbf{1 a}$.

The ${ }^{1} \mathrm{H}$ NMR spectrum of $\mathbf{1 a}$ at room temperature shows well-separated signals for the ligands (Fig. 2). The $\mathrm{H}^{2}, \mathrm{H}^{4}$ and $\mathrm{H}^{7}$ proton signals are shifted downfield, which is normally observed for protons adjacent to coordinated nitrogens. ${ }^{10}$ In particular, a single resonance at $\delta 6.50$ for the para-phenylene protons, about $\delta 0.75$ upfield from the free benzbix $(\delta 7.25)$, was observed. Considering the solid-state structure, the para-phenylene protons should give two sets of peaks: a singlet with an upfield signal for the two adjacent protons $(\mathrm{H}-\mathrm{C} 34$ and $\mathrm{H}-\mathrm{C} 35$ in Fig. 1 or $\mathrm{H}^{9 \prime}$ in Fig. 2) located directly above the shielding zone of the dhnq and a singlet with a downfield (or no significant shift) signal for the remaining two protons ( $\mathrm{H}-\mathrm{C} 37$ and $\mathrm{H}-\mathrm{C} 38$ in Fig. 1 or $\mathrm{H}^{9}$ in Fig. 2). Hence, the single resonance for the para-phenylene protons in 1a suggests that the phenylene ring is rotating in solution and that metallacycle 1a can be depicted as a molecular rotor (Chart 1). ${ }^{11,12}$

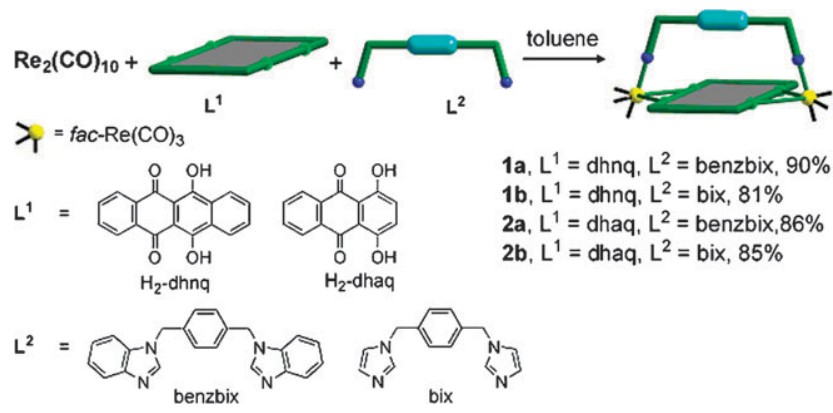

Scheme 1 The self-assembly of molecular rotors $\mathbf{1 a}, \mathbf{b}$ and $\mathbf{2 a , b}$. 


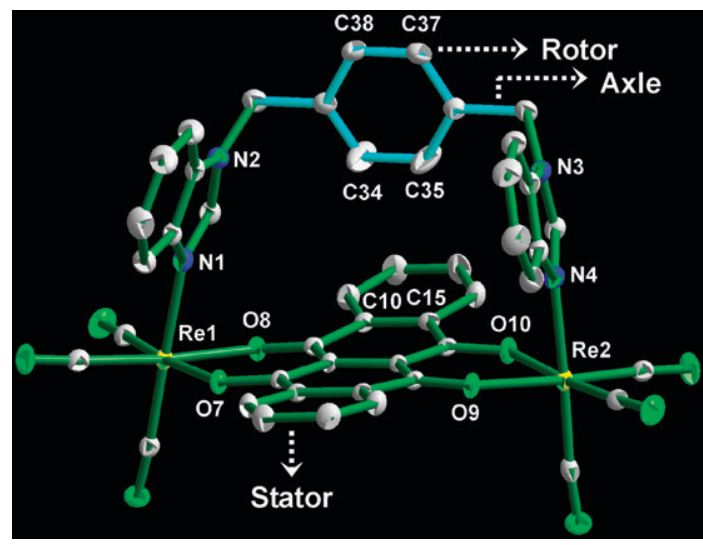

Fig. 1 An ORTEP plot (50\% probability) of 1a measured at 150(1) K. Axle and rotor bonds are indicated by cyan lines. Hydrogen atoms and guest toluene molecules are omitted for clarity.
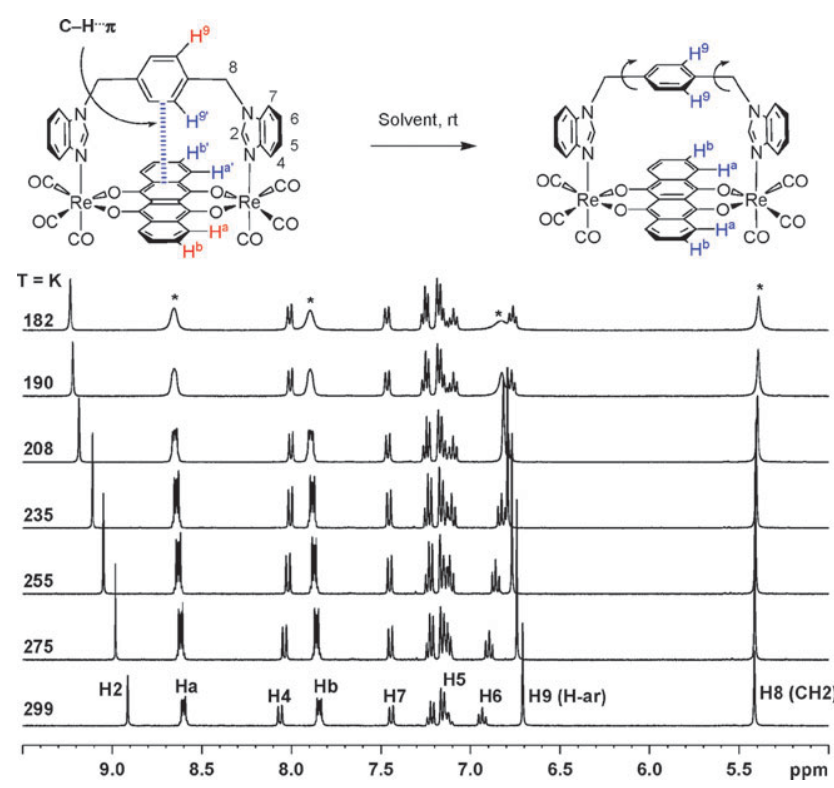

Fig. 2 A schematic representation of $\mathbf{1 a}$ in the solid (left, top) and solution (right, top) state. Variable temperature ${ }^{1} \mathrm{H}$ NMR spectra of 1a (bottom).

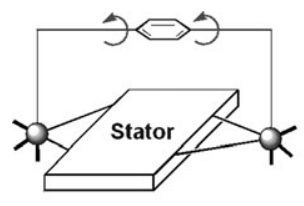

Rotor

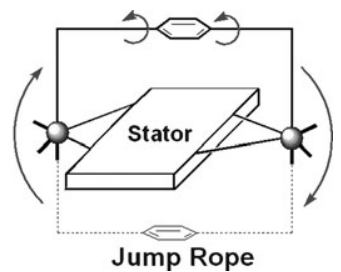

Chart 1 Models of a rotor and a jump rope.
Furthermore, the NOESY spectrum revealed NOEs from $\mathrm{H}^{9}$ to the $\mathrm{H}^{7-8}$ and $\mathrm{H}^{2}$ protons, and no NOEs to the dhnq protons.

The dynamic behavior of 1a was further probed by variable temperature ${ }^{1} \mathrm{H}$ NMR spectroscopy. A solution of 1a in acetone- $d_{6}$ was cooled from 299 to $182 \mathrm{~K}$ (Fig. 2). Below $208 \mathrm{~K}$, the proton signals corresponding to the para-phenylene unit $\left(\mathrm{H}^{9}\right)$, the methylene protons $\left(\mathrm{H}^{8}\right)$ and the dhnq protons $\left(\mathrm{H}^{\mathrm{a}, \mathrm{b}}\right)$ started to broaden. This indicates that at low temperature, the para-phenylene rotation was slowed. Complete decoalescence of the para-phenylene protons' signals could not be observed at an accessible temperature $(182 \mathrm{~K})$. The free energy of activation $\left(\Delta G^{\neq}=13.7 \mathrm{kcal} \mathrm{mol}^{-1}\right)$ of $\mathbf{1 a}$ was evaluated at a coalescence temperature of $208 \mathrm{~K}$ with a chemical shift difference of the resonances $(\Delta \nu=12.4 \mathrm{~Hz})$ calculated using an approximate method (Table S2, ESI $\dagger$ ). The energy barrier for paraphenylene rotation in 1a obtained experimentally was closely matched with a complete line-shape analysis $\left(14.5 \mathrm{kcal} \mathrm{mol}^{-1}\right.$; Table S2, ESI $\dagger$ ) corresponding to the $\mathrm{H}^{9}$ peak utilized in the calculation. The energy barrier to para-phenylene rotation was slightly higher than that observed for para-phenylene rotation $\left(9.3-10.4 \mathrm{kcal} \mathrm{mol}^{-1}\right)$ in some other reports. ${ }^{66,13}$ It is suggested that the $\mathrm{C}-\mathrm{H} \cdots \pi$ interactions between the dhnq and para-phenylene groups may play a role as an intrinsic brake function in mediating the restricted rotation of the rotor at low temperature, as indicated by the higher energy barrier of rotation. When a solution of 1a was warmed from 299 to $378 \mathrm{~K}$ in DMSO- $d_{6}$ (Fig. S7, ESI $\dagger$ ), no additional peaks were observed, which suggested thermal stability of the metallacycle. The proton signals of the benzimidazole units were shifted during the cooling and heating of the sample. This indicates that the benzimidazolyl units are flexible. Therefore, a syn/anti conformational exchange/equilibrium process is possible. The more downfield shift observed for the imidazolyl proton $\left(\mathrm{H}^{2}\right)$ indicates that this proton is moving away from the shielding zone when the temperature is lowered. Compared to the imidazolyl proton, the fused arene of the benzimidazolyl unit $\left(\mathrm{H}^{4-7}\right)$ is at the other end and shows the opposite effect, with less significant chemical shift changes. The two benzimidazolyl units are coordinated onto the axial sites of the two rhenium centers; it is impossible for the benzbix ligand to rotate around the two Re centers. Furthermore, swinging of the benzbix rope around the dhnq seems unlikely because of steric hindrance (the half-length of the dhnq $(5.69 \AA)$ is longer than the width of the rope (5.45 $\AA$; Fig. S2, ESI $\dagger)$ ). Hence, metallacycle 1a is not a jump rope ${ }^{12}$ and is best depicted as a rotor (Chart 1). The ${ }^{1} \mathrm{H}$ NMR spectra of $\mathbf{1 b}$ and $\mathbf{2 a , b}$ indicate that their para-phenylene groups rotate similarly to that in 1a.

In conclusion, neutral, Re-based metallacyclic rotors were assembled in a one-step synthesis in high yields. The metallacycles possess para-phenylene rotors that rotate in solution. These rotors can be considered a prototype of a neutral altitudinal rotor, and are almost the first such rotors to be reported. A key feature is the very easy assembly of the system and the use of some unique elements, which are promising for expansion to more complex structures.

We thank Academia Sinica and the National Science Council of Taiwan for financial support.

\section{Notes and references}

$\ddagger$ Synthesis and characterisation details

1a: A suspension consisting of a mixture of $\mathrm{Re}_{2}(\mathrm{CO})_{10}(217 \mathrm{mg}$, $0.33 \mathrm{mmol}$ ), benzbix (113 $\mathrm{mg}, 0.30 \mathrm{mmol}$ ) and $\mathrm{H}_{2}$-dhnq (97 $\mathrm{mg}$, $0.33 \mathrm{mmol})$ in toluene $(16 \mathrm{~mL})$ in a Teflon flask was placed in a steel bomb. The bomb was placed in an oven maintained at $160{ }^{\circ} \mathrm{C}$ for $48 \mathrm{~h}$ and then cooled to $25^{\circ} \mathrm{C}$. Good quality, dark green-colored single crystals of 1 a were obtained. The crystals were separated by filtration and washed with hexane. Yield: 90\% (363 mg). Anal. calc. for 
$\mathrm{C}_{46} \mathrm{H}_{26} \mathrm{~N}_{4} \mathrm{O}_{10} \mathrm{Re}_{2} \cdot\left(\mathrm{C}_{7} \mathrm{H}_{8}\right)_{0.5}: \mathrm{C}, 49.00 ; \mathrm{H}, 2.49 ; \mathrm{N}, 4.62$. Found: $\mathrm{C}$, 48.73; H, 2.24; N, 4.49\%. IR ( $\left.\mathrm{CH}_{3} \mathrm{COCH}_{3} / \mathrm{cm}^{-1}\right): 2010(\mathrm{C} \equiv \mathrm{O}), 1907$ $(\mathrm{C} \equiv \mathrm{O})$ and $1883(\mathrm{C} \equiv \mathrm{O})$. MS-FAB $(m / z): 1168.4\left[\mathrm{M}^{+}\right] .{ }^{1} \mathrm{H}$ NMR (DMSO- $d_{6}$ ): $\delta 8.88$ (s, $2 \mathrm{H}, \mathrm{H}^{2}$, benzbix), $8.45\left(\mathrm{~m}, 4 \mathrm{H}, \mathrm{H}^{1}, \mathrm{dhnq}\right), 7.95$ (d, $J=8.1 \mathrm{~Hz}, 2 \mathrm{H}, \mathrm{H}^{4}$, benzbix), $7.85\left(\mathrm{~m}, 4 \mathrm{H}, \mathrm{H}^{2}\right.$, dhnq), 7.62 (d, $J=8.1 \mathrm{~Hz}, 2 \mathrm{H}, \mathrm{H}^{7}$, benzbix), $7.22\left(\mathrm{~m}, 6.5 \mathrm{H}, \mathrm{H}^{5-6}\right.$, benzbix, toluene), $6.50\left(\mathrm{~s}, 4 \mathrm{H}, \mathrm{H}^{9}\right.$, benzbix), $5.35\left(\mathrm{~s}, 4 \mathrm{H}, \mathrm{CH}_{2}\right.$, benzbix) and 2.29 (s, $1.5 \mathrm{H}, \mathrm{CH}_{3}$, toluene).

1b: Dark green crystals of $\mathbf{1 b}$ were obtained by following a similar procedure to that for $1 \mathbf{a}$, using $\operatorname{Re}_{2}(\mathrm{CO})_{10}(217 \mathrm{mg}, 0.33 \mathrm{mmol})$, $\alpha, \alpha^{\prime}$-bis(imidazole-1-yl)-para-xylene (bix) $(89 \mathrm{mg}, 0.34 \mathrm{mmol}$ ) and $\mathrm{H}_{2}$-dhnq $(99 \mathrm{mg}, 0.34 \mathrm{mmol})$ in toluene $(16 \mathrm{~mL})$. Yield: $81 \%$ (287 mg). Anal. calc. for $\mathrm{C}_{38} \mathrm{H}_{22} \mathrm{~N}_{4} \mathrm{O}_{10} \mathrm{Re}_{2}: \mathrm{C}, 42.77 ; \mathrm{H}, 2.08 ; \mathrm{N}$, 5.25. Found: $\mathrm{C}, 42.99 ; \mathrm{H}, 2.14 ; \mathrm{N}, 5.30 \%$. IR $\left(\mathrm{CH}_{3} \mathrm{COCH}_{3} / \mathrm{cm}^{-1}\right)$ : $2009(\mathrm{C} \equiv \mathrm{O}), 1901(\mathrm{C} \equiv \mathrm{O})$ and $1886(\mathrm{C} \equiv \mathrm{O})$. MS-FAB $(\mathrm{m} / \mathrm{z})$ : $1066.13\left[\mathrm{M}^{+}\right] .{ }^{1} \mathrm{H}$ NMR (DMSO- $\left.d_{6}\right): \delta 8.44$ (m, 4H, $\mathrm{H}^{1}$, dhnq), 8.29 (s, $2 \mathrm{H}, \mathrm{H}^{2}$, bix), $7.90\left(\mathrm{~m}, 4 \mathrm{H}, \mathrm{H}^{2}, \mathrm{dhnq}\right), 7.04(\mathrm{t}, J=1.23 \mathrm{~Hz}$, $\left.2 \mathrm{H}, \mathrm{H}^{4}, \mathrm{bix}\right), 6.90\left(\mathrm{~s}, 2 \mathrm{H}, \mathrm{H}^{5}, \mathrm{bix}\right), 6.44\left(\mathrm{~s}, 4 \mathrm{H}, \mathrm{H}^{7}, \mathrm{bix}\right)$ and 5.01 (s, $4 \mathrm{H}, \mathrm{CH}_{2}$, bix).

$\S$ Crystal data for 1a: $\mathrm{C}_{46} \mathrm{H}_{26} \mathrm{~N}_{4} \mathrm{O}_{10} \mathrm{Re}_{2}, M_{\mathrm{r}}=1167.11$, orthorhombic, $a=12.7711(2), b=19.6190(3), c=17.1168(3) \AA, U=4288.72(12) \AA^{3}$, $T=295(2) \mathrm{K}$, space group Pnma, $Z=4,24620$ reflections measured, 5246 unique $\left(R_{\text {int }}=0.0732\right)$, which were used in all calculations. Final $R$ indices: $R 1=0.0669$ and $\mathrm{w} R 2=0.1338$ for 3793 reflections $[I>2 \sigma(I)] ; R 1=0.0896$ and $\mathrm{w} R 2=0.1431$ for all data. $\mathrm{GOF}=1.159 . \mathrm{CCDC} 717894 . \dagger$

Crystal data for $1 \mathrm{a} \cdot 0.5 \mathrm{C}_{7} \mathrm{H}_{8}: \mathrm{C}_{49.50} \mathrm{H}_{30} \mathrm{~N}_{4} \mathrm{O}_{10} \mathrm{Re}_{2}, M_{\mathrm{r}}=1213.17$, monoclinic, $a=9.9194(3), b=21.3024(8), c=21.7617(8) \AA$, $\beta=96.463(1)^{\circ}, U=4569.2(3) \AA^{3}, T=150(1) \mathrm{K}$, space group $P 2_{1} / n$, $Z=4,45222$ reflections measured, 10488 unique $\left(R_{\text {int }}=0.0357\right)$, which were used in all calculations. Final $R$ indices: $R 1=0.0313$ and $\mathrm{w} R 2=0.0826$ for 9496 reflections $[I>2 \sigma(I)] ; R 1=0.0369$ and $\mathrm{w} R 2=0.0886$ for all data. GOF $=1.197 . \mathrm{CCDC} 717895 . \dagger$

Crystal data for $1 \mathrm{~b}: \mathrm{C}_{38} \mathrm{H}_{22} \mathrm{~N}_{4} \mathrm{O}_{10} \mathrm{Re}_{2}, M_{\mathrm{r}}=1067.00$, orthorhombic, $a=23.8693(6), b=25.9927(7), c=10.8655(3) \AA$, $U=6741.3(3) \AA^{3}, T=150(1) \mathrm{K}$, space group Cmca, $Z=8,32508$ reflections measured, 3959 unique $\left(R_{\text {int }}=0.0367\right)$, which were used in all calculations. Final $R$ indices: $R 1=0.0222$ and $\mathrm{w} R 2=0.0451$ for 3610 reflections $[I>2 \sigma(I)] ; R 1=0.0260$ and $\mathrm{w} R 2=0.0464$ for all data. $\mathrm{GOF}=1.111 . \mathrm{CCDC} 717896 . \dagger$

Crystal data for 2 b. $\mathrm{C}_{3} \mathrm{H}_{6} \mathrm{O}: \mathrm{C}_{37} \mathrm{H}_{26} \mathrm{~N}_{4} \mathrm{O}_{11} \mathrm{Re}_{2}, M_{\mathrm{r}}=1075.02$, monoclinic, $a=22.3424(8), b=20.9297(7), c=7.9283(3) \AA$, $\beta=98.913(1)^{\circ}, U=3662.7(2) \AA^{3}, T=150(1) \mathrm{K}$, space group $C 2 / m, Z=4,17827$ reflections measured, 4325 unique $\left(R_{\text {int }}=0.0561\right)$, which were used in all calculations. Final $R$ indices: $R 1=0.0460$ and $\mathrm{w} R 2=0.1081$ for 3497 reflections $[I>2 \sigma(I)] ; R 1=0.0627$ and $\mathrm{w} R 2=0.1224$ for all data. GOF $=1.189 . \mathrm{CCDC} 717897 . \dagger$

1 (a) Molecular Motors, ed. M. Schliwa, Wiley-VCH, Weinheim, 2003; (b) R. D. Vale and R. A. Milligan, Science, 2000, 288, 88-95; (c) M. Schliwa and G. Woehlke, Nature, 2003, 422, 759-765; (d) B. Yurke, A. J. Turberfield, A. P. Mills, Jr, F. C. Simmel and J. L. Neumann, Nature, 2000, 406, 605-608; (e) B. Alberts, Cell, 1998, 92, 291-390.

2 (a) T. R. Kelly, H. D. Silva and R. A. Silva, Nature, 1999, 401, 150-152; (b) J. Vicario, N. Katsonis, S. B. Ramon, C. W. W. Bastiaansen, D. J. Broer and B. L. Feringa, Nature, 2006, 440, 163; (c) D. A. Leigh, J. K. Y. Wong, F. Dehez and F. Zerbetto, Nature, 2003, 424, 174-179; (d) M. F. Hawthorne, J. I. Zink, J. M. Skelton, M. J. Bayer, C. Liu, E. Livshits, R. Baer and D. Neuhauser, Science, 2004, 303, 1849-1851; (e) J. D. Badjic, V. Balzani, A. Credi, S. Silvi and J. F. Stoddart, Science, 2004, 303, 1845-1849; (f) T. Muraoka, K. Kinbara and T. Aida, Nature, 2006, 440, 512-515; $(g)$ Molecular Machines and Motors, ed. J.-P. Sauvage, Springer, Berlin, 2001.
3 (a) For a special issue on molecular machines, see: Acc. Chem. Res., 2001, 34, 409-522; (b) E. R. Kay, D. A. Leigh and F. Zerbetto, Angew. Chem., Int. Ed., 2006, 46, 72-191; (c) G. S. Kottas, L. I. Clarke, D. Horinek and J. Michl, Chem. Rev., 2005, 105, 1281-1376; (d) Y. Shirai, J. F. Morin, T. Sasaki, J. M. Guerrero and J. M. Tour, Chem. Soc. Rev., 2006, 35, 1043-1055; (e) G. Rapenne, Org. Biomol. Chem., 2005, 3, 1165-1169; (f) S. Fournier-Bidoz, A. C. Arsenault, I. Manners and G. A. Ozin, Chem. Commun., 2005, 441-443; (g) Y. Shirai, J. F. Morin, T. Sasaki, J. M. Guerrero and J. M. Tour, Chem. Soc. Rev., 2006, 35, 1043-1055; (h) T. Akutagawa, K. Shitagami, S. Nishihara, S. Takeda, T. Hasegawa, T. Nakamura, Y. Hosokoshi, K. Inoue, S. Ikeuchi, Y. Miyazaki and K. Saito, J. Am. Chem. Soc., 2005, 127, 4397-4402; (i) C. W. Chiu, C. C. Lai and S. H. Chiu, J. Am. Chem. Soc., 2007, 129, 3500-3501.

4 (a) T. A. V. Khuong, J. E. Nunez, C. E. Godinez and M. A. Garcia-Garibay, Acc. Chem. Res., 2006, 39, 413-422; (b) S. D. Karlen and M. A. Garcia-Garibay, Top. Curr. Chem., 2006, 262, 179-227; (c) M. A. Garcia-Garibay, Proc. Natl. Acad. Sci. U. S. A., 2005, 102, 10771-10776; (d) T. A. V. Khuong, H. Dang, P. D. Jarowski, E. F. Maverick and M. A. GarciaGaribay, J. Am. Chem. Soc., 2007, 129, 839-845; (e) J. R. Gardinier, P. J. Pellechia and M. D. Smith, J. Am. Chem. Soc., 2005, 127, 12448-12449.

5 (a) L. Wang, F. Hampel and J. A. Gladysz, Angew. Chem., Int. Ed., 2006, 45, 4372-4375; (b) A. J. Nawara, T. Shima, F. Hampel and J. A. Gladysz, J. Am. Chem. Soc., 2006, 128, 4962-4963; (c) T. Shima, F. Hampel and J. A. Gladysz, Angew. Chem., Int Ed., 2004, 43, 5537-5540; (d) R. Romeo, S. Carnabuci, L. Fenech, M. R. Plutino and A. Albinati, Angew. Chem., Int. Ed., 2006, 45, 4494-4498; (e) I. Hyla-Kryspin, S. Grimme and J.-P. Djukic, Organometallics, 2009, 28, 1001-1013; $(f)$ A. Berger, A. de Cian, J.-P. Djukic, J. Fischer and M. Pfeffer, Organometallics, 2001, 20, 3230-3240.

6 (a) M. Wahl, M. Stöhr, H. Spillmann, T. A. Jung and L. H. Gade, Chem. Commun., 2007, 1349-1351; (b) S. Bracco, A. Comotti, P. Valesia, B. F. Chmelka and P. Sozzani, Chem. Commun. 2008, 4798-4800; (c) L. Wang, T. Shima, F. Hampel and J. A. Gladsyz, Chem. Commun., 2006, 4075-4077; (d) T. F. Magnera and J. Michl, Top. Curr. Chem., 2005, 262, 63-67; (e) D. Horinek and J. Michl, Proc. Natl. Acad. Sci. U. S. A., 2005, 102, 14175-14180.

7 (a) D. C. Caskey, R. K. Shoemaker and J. Michl, Org. Lett., 2004, 6, 2093-2096; (b) D. C. Caskey and J. Michl, J. Org. Chem., 2005, 70, 5442-5448; (c) D. C. Caskey, B. Wang, X. Zheng and J. Michl, Collect. Czech. Chem. Commun., 2005, 70, 1970-1985.

8 (a) P. H. Dinolfo, M. E. Williams, C. L. Stern and J. T. Hupp, J. Am. Chem. Soc., 2004, 126, 12989-13001; (b) C. M. Lukehart, in Fundamental Transition Metal Organometallic Chemistry, Brooks/ Cole Publishing Company, Monterey, 1985, ch. 3, p. 81.

9 (a) S. Tsuzuki, K. Honda, T. Uchimaru, M. Mikami and K. Tanabe, J. Am. Chem. Soc., 2000, 122, 3746-3753; (b) T. Morimoto, H. Uno and H. Furuta, Angew. Chem., Int. Ed., 2007, 46, 3672-3675 and references therein.

10 C. Y. Su, Y. P. Cai, C. L. Chen, M. D. Smith, W. Kaim and H. C. zur Loye, J. Am. Chem. Soc., 2003, 125, 8595-8613.

11 T. C. Bedard and J. S. Moore, J. Am. Chem. Soc., 1995, 117, 10662-10671.

12 M. Ohkita, K. Ando, K. Yamamoto, T. Suzuki and T. Tsuji, Chem. Commun., 2000, 83-84.

13 (a) D. R. Whitney and R. Yaris, Macromolecules, 1997, 30, 1741-1751; (b) M. Hutnik, A. S. Argon and U. W. Suter, Macromolecules, 1991, 24, 5970-5979. 